\title{
Reflecting on Islam in America
}

\author{
July 5-7, 2002 • Chicago, Illinois
}

"The strength of America is in its diversity, and this diversity includes the Islamic component, which is part of the American mainstream now." So proclaimed ISNA secretary general Sayyid M. Syeed while inaugurating the sixth annual ISNA Islam in America Conference, which is now part of the American academic calendar.

Held in Chicago on July 5-7, four conferences were featured: Islam in America, Islam among Latino Americans, Islam in American Prisons, and Muslim Refugee Resettlement in America. The mainstream American media was there in full to cover these events.

In his inaugural address, Syeed said that Muslims must continue to shape their public identity as they further integrate into mainstream American society. He added that while public perceptions about Muslims and Islam have improved over the last 30 years, there is still work to be done. He stated that ISNA will continue to serve Muslim Americans and promote understanding among all Americans, and that INSA has received a federal faith-based initiative grant for a project.

Mary Ann Peters, American ambassador to Bangladesh, remarked in her keynote address that America derives its strength from diversity and stressed that there is no acceptable level of intolerance in America. She informed the audience that she had reached out to over 2,000 Bangladeshi religious leaders to promote womens' rights in their country, and that promoting democracy overseas serves American interests. She would like to see better relations between the U.S. and Muslim countries, and mentioned that the American government has accepted her suggestion of regular exchanges of religious scholars between the two countries.

Shaikh Hamza Yusuf focused on the Prophet's conduct and reminded everyone that he never repaid persecution, insults, or injury with anger or in kind. Addressing the mainstream media's treatment of Muslims, Yusuf said that instead of simply criticizing the media, Muslims must form an organization similar to the Anti-Defamation League that could correct and inform their detractors. Dr. David Schwartz, another keynote speaker who recently retired as religious services administrator for the Federal Bureau of Prisons, said that Islam is a positive element in inmates' lives. He vehemently rejected the insinuation that American prisons are being used as breeding grounds for terrorists. 
The 3-day conference brought together scholars, researchers, and community workers and leaders. The "Islam in America" conference featured, among many others, Abidullah Ghazi (chair, Iqra International Education Foundation, Chicago) traced the history of the madrassa system. He stated that Muslims need to create a "modern madrassa" in North America where the medium would be English and the syllabus comprehensive and enriching. Sven Talha de Backer (Iqra) emphasized that education is the key to dispelling misconceptions about Islam. Purdue economist Ali Al Jamal said that marginalizing scholars and scholarship has led to degeneration in the Muslim Ummah. Irfan Ahmed Khan (World Parliament of Religions), who believes that Muslims should rely on their own reasoning to understand Islam, stressed the need for "progressive Islam" as compared to "traditional Islam."

Anas Malik (Depauw University) pointed out the corporate mass media establishes the terms and scope of policy debate by setting agendas, framing issues, and defining language and discourse. Muslims, he said, need to invest heavily in media and pursue campaigns, such as CAIR'S Action Alerts, that play a crucial role in mobilizing the community. Muqtedar Khan (Adrian College) focused on the urgent need to build bridges with civil society and stressed that Muslims should work toward the secularization of the U.S. Faizan M. Haq (Cora P. Maloney College) spoke on the new image for Muslims in America. Scott Alexander (Catholic Theological Union), discussed the "Inalienable Rights: Muslims in the U.S. after September 11th."

Mir Maqsood Ali (University of Illinois - Urbana-Champaign) spoke on the Muslim contribution to America. He highlighted the work of Fazlur Rahman Khan, a structural engineer effectively recognized as the architect of the world-famous Sears Tower in Chicago. Rajab Ali highlighted his contributions as a Fremont, CA, city commissioner, while Safaa Zarzour focused on politics in Bridgeview, IL.

Finance-related issues were discussed by Mahmud ElGamal (Rice University), Bassam Osman (NAIT chairman), and Monem Salam (Morgan Stanley). Mohammad Shafiq (Rochester, NY) reflected on interfaith dialogue, and Class Ehlers introduced the National Interfaith Hospitality Network. David Zinner spoke on Jewish burials and proposed that Muslims should collaborate in making death commercial-free. California attorney Omar Farooqui related his successful pursuit of a highly acclaimed Indian magazine that had slandered ISNA.

During the "Islam among Latino Americans" conference, Syeed introduced the first-ever issue of Islamic Horizons to focus exclusively on 
Latino Muslims. The conference recommended the formalization of Latino Muslim institutions to pursue outreach more effectively. Participants agreed to form a national nonprofit organization consisting of activists in the field and other Hispanic Muslim organizations. Ahmad Totonji, a founder of MSA, informed the panel that several Muslim philanthropists have published literature in Spanish. This will help fill the gap in Spanishlanguage literature on Islam.

At the conference on "Islam in American Prisons," Imam Umar Abdulraheem (Butner, NC) spoke on the halfway houses that help prepare former inmates for normal life. Mohammed Firdosi spoke on the Islamic impact on prisoners and street gangs.

At the conference on "Muslim Refugee Resettlement in America," Huseyn Abiva (Iqra) spoke on the European experience in North America. Frank Beane (Kent State) highlighted aspects of his research on "The Cultural Jihad during the Antebellum and Its Survivors" and described how enslaved Muslims in the South tried to preserve their faith. Dr. Lawrence Tamatea (University of New South Wales, Australia) related the growth of Islam Down Under. Abdul of Basit (University of Chicago) addressed the rehabilitation of Muslim refugees in America.

Amana Mutual Fund, the Association of Muslim Social Scientists (AMSS), the American Council for the Study of Islamic Societies, The Christian Theological Union - Bernardin Center, and Guidance Financial Group served as conferences cosponsors.

The ISNA conferences garnered praise for offering both learning and networking opportunities. 